\title{
Advisor's Roles and Responsibilities under the Vocational Education Commission in 3 Southern Border Provinces, Thailand
}

\author{
Ariya Kuha
}

\begin{abstract}
Education is the way to enhance knowledge, personality, thinking skills of students, lack of responsibility and motivation, both on the part of the teacher and the student to poor level of development of teachers. This research aimed to study the advisor's roles and responsibilities under the vocational education commission. 284 advisors from Yala, Pattani, Narathiwas in 2012 from southern border provinces in Thailandwere the subject of the study. The questionnaire was administered with .94 of reliability. The results showed that the advisor's roles and responsibilities were highin all aspects and that the highest was ethics aspect following by characteristics, personality and human relationship, academic and skill aspects respectively. Comparing on the advisor's roles and responsibilities found that level of education, salary, teaching loadand working positionhad statistically significant differences.
\end{abstract}

Index Terms-Advisor's roles and responsibilities, vocational education commission.

\section{INTRODUCTION}

Human development is the way to build up social development. Quality of society brings to focus onthe process of education. The purpose of education, on all levels, is for each and every person-both within the collective whole of humanity and individually as a vitally necessary, and fully whole and contributing part-to ultimately reach the full realization of what it means to be human [1]. The school is a great resource for guidance. Its fundamental purpose is guidance which aims at developing good habits, skills, conduct, ideals and values. The school's activities such student unions, clubs, camps and different societies help the student discover their own abilities and help develop them. The home is another resource. It is to inculcate good living habits, develop good behavior and desirable interests and hobbies. In this regard, the school and the home should cooperatein utilizing theirre sources for the development of the students [2]. Since the school as a social institution is conceived as the proper setting for learning experiences and everything which promotes and helps the process is the real concern of the teachers. In this sense, teachers affect the lives of the students by helping the blossoming of their personalities. The influence of the teacher thus goes beyond the school. Administrator and teachers especially the advisor have a great deal of interest in these responsibilities as an approach to influence the students. This necessarily needs not be through a lecture course; it could be a subject dealt with in advice. As the aim of education

Manuscript received May 23, 2013; revised August 1, 2013.

Ariya Kuha is with the Prince of Songkla University, Thailand (e-mail: ariyakuha@gmail.com). aims to help the teacher to understand the student in order to be successful in their students' future lives. Learning how to learn is one of the key elements of education. Schools and teachers need to teach the students how to find information they will need once they leave school. An advisor is a person who gives advice to a student in school or educational institution, the advisor is also an individual who provides advice, information, or suggestions to the judge [3]. Its structure often studied not only in taking research but also in study and real world settings. So the advisor system is one among the processes of education which the teacher will be greatly responded to the students who come from different culture, environment and background. Meaningful advice given by an advisor can influence the way it is received by the students. The teacher is responsible for overseeing student's academic and social progress in the school and provides parents with the opportunity to have a personal contact within the school. The responsibilities of an advisor in teacher advisor system are [4]: 1)to review student's report in order to identify critical information about academic strategies and conditions 2) to make meeting arrangement with the student on a regular basis 3) to contact the parents of each student at least after each reporting period 4) to monitor the academic progress of each student in the advisee group 5) to provide support for exam preparation and other extra help 6) to be aware of each student's activity and the overall involvement in the school program 7) to collect, proof reading and assembling report cards 8) to refer social or behavioral issues to appropriate student services personnel 9) to maintain a file of contact information of each student and 10) to communicate relevant information about students to appropriate people. This results in students having varied in attitude, personality, knowledge and experience. Besides, a person is a unity in complexity; these different dimensions must be understood in their to tality[5].In this regard an advisor could help the student an effective teaching skills going hand-and-hand. As such the advisor can play a very important role in a student's successful life. Good advising can help students' abilities to make good choices, improve their critical thinking skills, and set attainable goals that are in their best interest. So Advisors are in the position to help students to establish realistic goals and objectives and encourage them to be responsible for their own progress and success. Thus, advising fosters the development of the whole student who is a self-directed, motivated, responsible decision-maker and encourages the successful completion of knowledge requirements and timely education [6]. As far as this study is concerned the data lead-out to know the roles and responsibilities of the advisors and will also come to know how the advisors perceived themselves in regard to the roles and responsibilities. Because of achievement of the students in 
the future years to come in life will be affected adversely or enhanced by what happened in the early year of school or college.If in the early years a sense of inadequacy and inferiority is allowed to develop there is the danger that may dispose the student to despair his/her skills.

\section{Conceptual Framework}

The conceptual framework of this study shown in Fig. 1.

\begin{tabular}{|l||l|}
\hline Roles and & \multicolumn{1}{c|}{ Advisors } \\
Responsibilities & Sex \\
on various aspects & Age \\
Academic & Level of Education \\
Ethics & Salary \\
Skills & Family Condition \\
Personalityand Human & Working Experiences \\
Relationship & Teaching Load \\
\hline
\end{tabular}

Fig. 1. The conceptual framework showing the advisor and their roles and responsibilities.

\section{Methodology}

\section{A. Research Type}

This present study was a descriptive research in nature. The advisor's roles and responsibilities comprise of academic, ethics, skills, personality and human relationship and characteristics aspects.

\section{B. Population/Sample}

The study was conducted where there were 13vocational education institutions in the city of Yala, Pattani, Narathiwat in the utmost southern border provinces of Thailand in the year 2012.The sample of the study were 284 from among 316 advisors under vocational education commission; they are government officers, government service officers and employed officers in accordance with age, sex, level of education, salary, family condition, working experiences, teaching load and working position. The instruments of the study were a questionnaire of the advisor's roles and responsibilities under the vocational education commission with .94 of reliability. For research hypothesis percentage, mean, standard deviation, t-test,f-test and LSD were used to analyses the data collected.

\section{General Objectives of the Study}

This study aims to explore the advisor's roles and responsibilities under the vocational education commission in 3 southern border provinces in Thailand.

\section{Specific Objectives of the Study}

1) To study the advisor's roles and responsibilities under the vocational education commission in 3 southern border provinces in Thailand in the aspect of academic, ethics, skills, personality and human relationship and characteristics aspects.

2) To compare and investigate the advisor's roles and responsibilities according to age, sex, level of education, salary, family condition, working experiences, teaching load and working position.

3) To find out the problems and difficulties of the advisor's roles and responsibilities under the vocational education commission in 3 southern border provinces in Thailand.

\section{E. Hypothesis of the Study}

1) The advisor's roles and responsibilities under the vocational education commission in 3 southern border provinces of Thailand were high.

2) The advisor's roles and responsibilities under the vocational education commission in 3 southern border provinces of Thailand were differentially expressed according to age, sex, level of education, salary, family condition, working experiences, teaching load and working position.

\section{RESULTS}

\begin{tabular}{|c|c|c|}
\hline Variables & Frequency & Percentage \\
\hline \multicolumn{3}{|l|}{ Sex } \\
\hline Male & 135 & 47.5 \\
\hline Female & 149 & 52.5 \\
\hline \multicolumn{3}{|l|}{ Age } \\
\hline $20-30 \mathrm{yrs}$ & 76 & 26.8 \\
\hline 30-39 yrs. & 104 & 36.6 \\
\hline $40-49$ yrs. & 66 & 23.2 \\
\hline $50-59$ yrs & 38 & 13.4 \\
\hline \multicolumn{3}{|l|}{ Level of Education } \\
\hline Under graduation & 9 & 3.2 \\
\hline B.A. & 216 & 76.1 \\
\hline M.A. & 59 & 20.8 \\
\hline \multicolumn{3}{|l|}{ Salary } \\
\hline Lower 15,000 baht & 134 & 47.2 \\
\hline $15,001-20,000$ baht & 68 & 23.9 \\
\hline $20,001-25,000 \mathrm{baht}$ & 9 & 3.2 \\
\hline $25,001-30,000$ baht & 28 & 9.9 \\
\hline $30,001-35,000$ baht & 23 & 8.1 \\
\hline $35,001-40,000 \mathrm{baht}$ & 22 & 7.7 \\
\hline \multicolumn{3}{|l|}{ Family Condition } \\
\hline Single & 107 & 37.7 \\
\hline Marriage & 171 & 60.2 \\
\hline Divorce & 6 & 2.1 \\
\hline \multicolumn{3}{|l|}{ Working Experience } \\
\hline $1-5 \mathrm{yrs}$ & 100 & 35.2 \\
\hline $6-10 \mathrm{yrs}$ & 78 & 27.5 \\
\hline Variables & Frequency & Percentage \\
\hline \multirow{3}{*}{$\begin{array}{c}11-15 \mathrm{yrs} \\
16-20 \mathrm{yrs} \\
+20 \mathrm{yrs}\end{array}$} & 49 & 17.3 \\
\hline & 28 & 9.9 \\
\hline & 29 & 10.2 \\
\hline \multirow{12}{*}{$\begin{array}{l}\text { Teaching Load } \\
5-10 \mathrm{hrs} \\
11-15 \mathrm{hrs} \\
16-20 \mathrm{hrs} \\
21-25 \mathrm{hrs} \\
26-30 \mathrm{hrs} \\
31.35 \mathrm{hrs} \\
36-40 \mathrm{hrs} \\
\text { Working Position. } \\
\text { Government officers, } \\
\text { Government Service officers } \\
\text { Employed officers }\end{array}$} & 46 & 16.2 \\
\hline & 32 & 11.3 \\
\hline & 64 & 22.5 \\
\hline & 65 & 22.9 \\
\hline & 51 & 18.0 \\
\hline & 22 & 7.7 \\
\hline & 4 & 1.4 \\
\hline & & \\
\hline & & \\
\hline & 152 & \\
\hline & 89 & $\begin{array}{l}55.5 \\
31.3\end{array}$ \\
\hline & 43 & 15.1 \\
\hline Total & 284 & 100 \\
\hline
\end{tabular}

The finding of this study (See Table I) showed that 
percentage of the responses of 284 advisors and above representing 135,149 were males and female $(47.5 / 52.5 \%$ respectively), they are 20-29, 30-39, 40-49,50-59 years of age (26.8/36.6/23.2/13.4\% respectively) completed their education at under graduation, B.A. and M. A. (3.2, 76.1 and $20.8 \%$ respectively) with salary/month below 15,000 bht., 15,001-20,000 bht., 20,001-25,000 bht., 25,00130,000bht., 30,001-35,000 bht., 35,001-40,000bht.(47.2, $23.9,3.2,9.9,8.1,7.7 \%$ respectively) being single, married and divorce $(37.7,60.2$ and $2.1 \%$ respectively) their working experience/years between 1-5, 6-10, 11-15, 16-20 and more than $20(35.2,27.5,17.3,9.9,10.2 \%$ respectively) teaching load hour/week between 5-10, 11-15, 16-20, 21-25, 25-30, 31.35 and 36-40 hrs. (16.2, 11.3, 22.5, 22.9, 18.0, 7.7 and $1.4 \%$ respectively) is being as employed officers, service officers, government officers $(15.1,31.3$ and 53.5\% respectively).

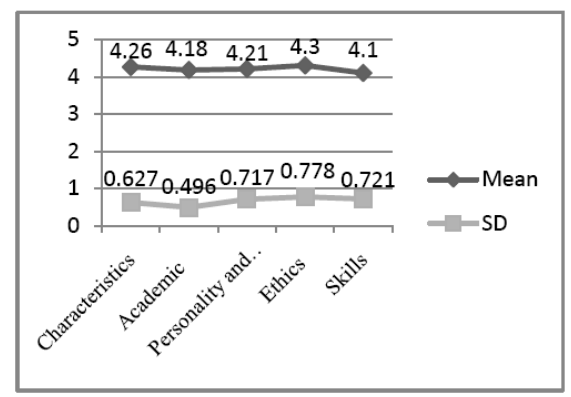

Fig. 2. The advisor's roles and responsibilities.

The Fig. 2 showed in the above table that the advisor's roles and responsibilitieswere high in all aspects and that the highest was ethics aspectfollowing by characteristics, personality and human relationship, academic and skills aspects respectively.

TABLE II:THE RESULT OF COMPARING MEAN OF ADVISOR'S ROLES AND RESPONSIBILITIES ON VARIOUS VARIABLES

\begin{tabular}{|ccc|}
\hline $\begin{array}{c}\text { Comparison of } \\
\text { Variables }\end{array}$ & Aspects & Level of \\
Sex & - & Significant \\
Age & - & No Significant \\
Level of Education & Academic & at.05 \\
Salary & Characteristics & at.00 \\
& Academic & at.000 \\
Family Condition & Skills & at.05 \\
WorkingExperience & - & No significant \\
Teaching loadWorking & Characteristics & No significant \\
Position & Characteristics & at.05 \\
& AcademicPersonali & at.05 \\
& tyand & at.05 \\
& HumanRelationshp & \\
& & \\
& & \\
& & \\
& & \\
& &
\end{tabular}

The Table II revealed that the advisor's roles and responsibilities with regard tolevel of education showed the significant differences at .05 level only the aspect of academic while salary were at $.00, .000$ and .05 level on the aspect of characteristics, academic and skills respectively. Accordingly teachingloadalso showed the significant differences onlyon the aspect of characteristics at .05 level.Workingposition was found that the significant differenceswere at.001, .05 and .05 on the aspect of characteristics, academic and personality and human relationship respectively.

\section{CONCLUSIONS AND RECOMMENDATIONS}

From the data analysis it can be concluded that the advisor's roles and responsibilities were at high. In the aspects of comparing on the advisor's roles and responsibilities, it is found that the level of education, salary, teaching load and working position had statistically significant differences among the advisors. When focusing onlevel of education, it is found that the advisors with lower of education performed their roles and responsibilities higher than those who were higher. Likewise salary, the lower income of the advisors responsible for their roles and responsibilities the higher as well as teaching load. Finally with working position the advisors i.e., employed officers, service officers, and government officers, it is found that those are employed officers performed their roles and responsibilities the highest follow by those service officer sand government officers respectively.

Additionally, this research brought about that the administrator should clearly and concretely ways to define advisor's system and policy in developing the advisors competency and also not only set up systematic and practical methods and implementation of guidelines in all aspects for them to follow in the same directions but also set up mentor's advisor system and maintaining currency in academic advising trends and techniques through professional development. The administrator should solve an urgently problem i.e., 1) misbalancing on work responsibilities, salary among government officers, government service officers and employed officers

in regard of teaching hour and other duties not regarded as lecturer's workload and 2) strengthening its system, 3) selection of advisors should set up based on personality, characteristic, willingness and service mind, 4) evaluating advisor's performance as perceived by student, 5) establish an advisor's seminar in providing them additional knowledge of being a good advisor, concerning the student's problem and individual differences. 6) Reporting to their parents continuously. Besides, the advisor themselves must realize the roles and responsibilities in giving advises to fully perform. As considering, there was an incongruent of meeting schedule between advisors and students. Moreover, students should understand the profit of asking advise in a the way that this will guide them as being in higher education's efficient life.

\section{ACKNOWLEDGEMENT}

This work was support by the grant of Prince of Songkla University and Pattani Vocational Education College under Vocational Education Commission in 2012-2013. 


\section{REFERENCES}

[1] C. Luview. (December 2011). What should thepurpose of education be? [Online]. Available: http://www.ted.com/conversations/7491/.

[2] N. Rao, Education Psychology, New Delhi: Wiley Eastern Limited, 1990.

[3] USLegal.Teacher Advisor System Law \& Legal Definition, Alabama, 2011.

[4] K. Naylon, Roles and Responsibilities of Advisors and Advisee, NC: High Point University, 2012.

[5] N. Somnath, M. C. Ghosh, and S. Adhikari, "Impact of physical education teacher's training programmer on development of purpose in life," International Journal of Scientific and Research Publication, vol. 2, no. 9, September, 14, 2012.

[6] National Academic Advising Association. (2005). Thestatement of core values of academic advising.The National Academic Advising Association. [Online]. Available: http://www.nacada.ksu.edu/Resources/Clearinghouse/ViewArticles/Core-values-position.

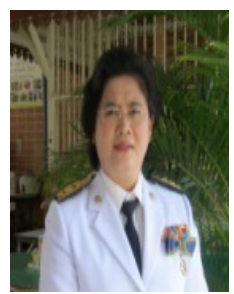

Ariya Kuha received her bechalor's degree in psychology and guidance from Prince of Songkla University (PSU) in 1986 and also her master DEGREE and Ph.D. in educational psychology from Panjab University, Chandigarh, India in 1992. She iscurrently an assistance professor in educational Psychology at the Department of Psychology and Guidance, Facultyof Education, Prince of Songkla University where she is also the Assistant President for Student Development, Student Affairs Divisionduring 2003-2006. And also Head of the Department of Psychology and Guidance during 20062010 as well as Vice Dean for Graduate Program andResearch, Facultyof Education. Currently she is the Senate of Prince of Songkla University. She has vast teaching experience as well as a guest speaker in the area of motivation, attitude, thinking skills, positive thinking, teacher's roles, and educational psychology. She has been activelyinvolved in research programmed conferences and publications and had the opportunity to present paper at international conferences held Thailand, Indoneasia and China. Ariya Kuha is the author of several books regarding psychology like: Motivation and Emotion, Psychology in Daily Life and Social Psychology. Moreover, she also published a plenty of research articles ie., Public Mind and Lifestyle of Prince of Songkla University's Students, Pattani Campus, Effects of Cooperative Learning by using CIRC program On Writing and Reading Ability On English Language Achievement Of Bilingual Students, Factors affecting academics probation of studentsof Prince of Songkla University, Pattani Campus, Effects of peer tutoring on learning achievement on mathematics of Mathayomsuksa Two students with different cognitive styles,Smoking Crisis at the Official Areas in Pattani, Thailand, Positive Psychology, Mind and Body: for fulfunctional Life, Emotion: Life Energy, etc. She is an editorial boardof Songklanakarin Journal of Social Science and Humanities and also a reader of various journals. 